\title{
'They don't care about us': representing the black postcolonial subject through the appropriation of Michael Jackson in Gabonese urban dance
}

\section{Alice Aterianus-Owanga}

To cite this article: Alice Aterianus-Owanga (2017): 'They don't care about us': representing the black postcolonial subject through the appropriation of Michael Jackson in Gabonese urban dance, Journal of African Cultural Studies, DOI: 10.1080/13696815.2016.1266464

To link to this article: http://dx.doi.org/10.1080/13696815.2016.1266464

曲 Published online: 09 Jan 2017.

Submit your article to this journal $\pi$

Џlll Article views: 14

Q View related articles $\longleftarrow$

View Crossmark data \lceil 


\title{
'They don't care about us': representing the black postcolonial subject through the appropriation of Michael Jackson in Gabonese urban dance
}

\author{
Alice Aterianus-Owanga \\ FMSH/IFAS, Johannesburg, South Africa
}

\begin{abstract}
This essay recounts both the intertwined history of the hip-hop appropriation and the identification to the figure of Michael Jackson in Gabon, from the 1980s to nowadays. It questions how transatlantic musical dialogues have provided the African youth with a way of representing a black subject freed from (post)colonial complexes. Drawing on historical and ethnographic data, this paper focuses on several imitators of Michael Jackson, and mainly on the case of Michael Anicet, a dancer who built his career and his fame on the imitation of Michael Jackson choreographies. It describes his pathway, his performances and how he transformed Michael Jackson's dances in order to 'gabonize' it, focusing mainly on his reception and appropriation of the song and choreography of the track 'They don't care about us'. This essay finally proves how the identification to global black icons has constituted the lever for an identity construction which combines nationalist claims and connections with a transnational blackness.
\end{abstract}

\section{KEYWORDS}

Dance; Gabon; Michael Jackson; blackness; nationalism/transnationalism

On an afternoon in February 2010, within the courtyard of a house located in the peripheral borough of Libreville named PK10, 10 young men are performing choreographies to the rhythm of Michael Jackson's hits that resound through a Hi-fi music system placed on a plastic garden table. Barefoot on the grass, dressed in tracksuits and T-shirts, or barechested, they position themselves in two lines beside an older dancer who leads the rehearsal. On the other side of the courtyard, a young woman observes the pirouettes, moon-walk steps and synchronized movements of the group. Aged from 18 to 30 years old, they are pupils, students, or dancers in hip-hop companies of Libreville. Each Monday, Wednesday and Friday, from 9 pm to midnight, they rehearse the routines choreographed by the director of this troupe who takes his inspiration from Michael Jackson.

Thin, rigorous but always joking and very sociable, this dancer is known in Libreville as 'Michael Anicet'.' Like many Africans who grew up during the 1980s, he discovered a passion for 'the King of Pop' with the songs and music videos of Bad and Beat It in 1982. Subsequently, he started to build his professional vocation around the imitation of the star and to create his own choreographies based on his videos, in order to 
'gabonize'3 Michael Jackson's legacy. Michael Anicet has become a key figure on the national musical stage, and he is currently considered by many people as the 'Gabonese Michael Jackson'. The big show that he organizes each year with his company at the French Institute of Libreville's theatre is sold out two nights a row, and he teaches Michael Jackson's dance style in a famous dance school of Libreville. His creation is, in fact, a special appropriation of Michael Jackson's dances and music, that aims to express simultaneously a connection to the globalized dance style that has created Michael Jackson; a claim of black pride and of common culture with black people from the United States; and a representation of locality and the nation through the gabonization of this dance and music style that has touched the people beyond any racial or gender lines (Rossiter 2012; Martin 2012). He explains his attempts in an interview:

Me, I am not called Michael Jackson, I am called Michael Anicet. This is the reason why I would like the people to be able to differentiate what Michael Jackson did from what I do. I would like to bring this Gabonese touch abroad: how, as a Gabonese, I dance Michael Jackson; how as Gabonese, me and my team, we live Michael Jackson; how Michael Jackson has influenced us in Gabon; how does the green-yellow-blue [Gabonese flag colors] represent Michael Jackson. ${ }^{4}$ (Interview with Michael Anicet, Dubai, February 2012)

Both Michael Anicet's creations and the broader history of hip-hop culture and dance practices observed as a part of Libreville's hip-hop movement reveal the core importance of Michael Jackson for the construction of new popular youth culture, as well as global identifications with a 'transnational blackness' (Marable and Agard-Jones 2008) in Gabon. ${ }^{5}$ Indeed, Michael Jackson has been adopted in Gabon in a strong correlation with the breakdance and hip-hop phenomenon of the 1980s, and is considered an emblem of black genius.

This essay recounts the intertwined history of hip-hop appropriation and the identification with Michael Jackson in Gabon, from the 1980s to the present day. Based on interviews with several previous imitators and fans of Michael Jackson and on a deep description of Michael Anicet's personal journey and creations, it questions how transatlantic musical dialogues (Matory 2006; Kelley 2012) have provided the Gabonese youth with a way of representing a black and Gabonese subject freed from (post)colonial complexes, while interacting with a global culture. It continues with several studies that have demonstrated the relevance of questioning anthropologically the notion of culture and cultural constructions through the lens of dance (Neveu Kringelbach and Skinner 2012), even if it does not always focus primarily on the performance itself.

This paper draws on historical and ethnographic data collected during a PhD in anthropology that dealt with the appropriation of rap music and hip-hop in Gabon, and also includes materials from a documentary movie that I directed about Michael Anicet and his company. ${ }^{6}$ It describes his pathways, his performances and how he transformed Michael Jackson's dances in order to 'gabonize' it, focusing mainly on his reception and appropriation of the song and choreography of the track 'They don't care about us', and to a lesser extent 'Black or white'. Following Michael Anicet and some other dancers' life stories, it analyses how the identification with African-American icons such as Michael Jackson has constituted the lever for an identity construction which combines nationalist claims and connections with a transnational black nation. A preamble regarding the issue of postcolonial agency through music and dance in Africa will provide a 
suitable introduction to our reflection about the cultural stakes of Michael Jackson's dance style in contemporary Gabon.

\section{Dancing postcolonial agency in Independent Africa}

In several African countries, music and dance have played a crucial part in the struggle for liberation or construction of alternative representations in postcolonial contexts (Turino 2000; Askew 2002; Plageman 2012). In urban Ghana, highlife dance bands and 'Saturday nights' were, for example, used during colonization to criticize colonial rule, and then employed in the postcolonial era to build a new independent Ghanaian identity (Plageman 2012). In Senegal, Hélène Neveu-Kringelbach has described how the revival of performance (dance, music and drama) had been a medium through which 'post-colonial elites sought to legitimize their power, and imagine a future for the new nation, [...] creating the illusion of continuity between the pre-colonial past and the present' (Neveu Kringelbach 2014, 2).

In Gabon, music and dance have been used since the end of colonization as a way to build urban and modern identities, and to connect with the idea of a common culture and history shared with the Afro-American and Afro-Caribbean worlds. Part of French Equatorial Africa from 1905 to 1958, the then colony of Gabon and its coastal capital were, during the 1950s, vibrating with several orchestras and live music venues, starting with the socalled bars-dancings (French word) where a mixed population used to dance to the rhythm of European and Caribbean music. In this period, the urbanization and development of the wood industry led to a demographic explosion in Libreville and other Gabonese towns, that welcomed the arrival of new populations coming from the inland villages or from foreign countries (Lasserre 1958).

New leisure and musical places also appeared in several districts of Libreville, where citizens listened and danced to the sounds of the city and the so-called évolués (advanced people) danced the foxtrot, polka, waltz, tango, rumba and biguine. ${ }^{7}$ During this period, Libreville was also strongly influenced by the rhythms and orchestras of neighbouring Congo and by the Brazzaville musical scene. Then, after the independence in 1960, Afro-Cuban music began to exert a growing impact in Libreville, which was pulsing to the sound of cha-cha-cha and pachanga, the sounds of which incarnated the emancipation and nationhood that African musicians started to claim (Dorsch 2010).

It is important to remember that in Gabon, Pan-Africanism and anticolonial struggles had had little impact in the political field and on popular culture until the 1970s (contrary to Senegal, Mali or Guinea) (M'Bokolo 2009), and that a major part of the political class had voted against the independence in 1958 (M'Bokolo 2009). Even after independence, Gabon maintained strong links with France, and a form of mutual dependence (Obiang 2007) was asserted, driving some observers to describe Gabon as a 'colonial enclave of French interest' (Reed 1987). French society and political organization were used as models for the creation of Gabonese institutions, ${ }^{8}$ and the conception of 'modern' culture needed for the development of the country was mainly inspired by the French colonizer, through clothing, gesture, ways of talking, and dance. ${ }^{9}$

The 1970s marked a real break in this cultural landscape: the explosion of African-American and Afro-Caribbean musical genres in global markets spread in Libreville and challenged European sonorities and models that represented social norms during the colonial era and still had a strong impact after independence. Jazz, funk and soul music 
brought new aesthetics and ideologies, in keeping with the discovery of the 'Black is beautiful' message. Among others, James Brown strongly contributed to this new connection, by offering two tremendous shows in Libreville in 1974 with his dancers and with the genius saxophonist Maceo Parker, at the invitation of the Gabonese president Omar Bongo. During this show, he shared his message of black pride and his image of a colourful and glittering blackness to the crowded audience. Then, in 1980, members of the presidential family welcomed Bob Marley, who also made his call to 'Back to Africa' and 'Africa Unite' resound for the Gabonese people. Finally, in 1992, it was Michael Jackson himself who landed in Libreville. These events provide proof of the emergence of new trends and interests towards the New World in Gabonese elites, appealed by the tremendous growth of American popular culture and music, spread in Europe and in Africa trough the expansion of media. This interest quickly extended among popular classes of the town, after local elites and media brought back to Libreville and its nights-clubs the sounds and dance styles in vogue in Europe and the United States.

In this lineage, a hip-hop movement appeared in Libreville at the mid-1980s, initially via the channel of the highest classes' circulations abroad. Whereas before, the youth used to confront each other during dance competitions where they mainly performed zaïko, soukouss or other Congolese dances, ${ }^{10}$ new dances and musical urban landscapes began to develop in the 1980s. In 1984, the coming of famous French hip-hop dancer Sidney and the popular spectacle that he gave to the youth with his dance group drove a new impulsion of creativity in Libreville's boroughs. Breakdance, robotic and smurf dance spread within youth choreographies and body practices, imposing new aesthetics.

At this time, dance groups gathered people from diverse ethnic origins, due to the interethnic composition of most of Libreville's districts (Kwenzi-Mikala 1992), and more broadly to the deep mobility, cultural exchanges and intermix between ethnic groups of Gabon's territory (Pourtier 1989). This transethnic dimension of youth solidarities would later be visible in the composition of most rap groups and hip-hop dance companies, echoing more generally the ideology of a multi-ethnic nation imposed by Omar Bongo since 1967 (Obiang 2007; Nguema Minko 2010; Ndombet 2009).

An investigation into this Libreville hip-hop music and dance scene which developed during the 1980s can hardly avoid engaging with the centrality of Michael Jackson. Indeed, for many artists that I met, the imitation of Michael Jackson has preceded the practice of other dance styles or rap. For the generation growing up during the 1980s, this dancer has been the lever for a new consciousness in African and black history, confirming the remarks of many, including Kelley (2012), Livio Sansone (Sansone, Barry, and Soumonni 2010) or Diawara (1998), regarding the importance of transatlantic dialogues and circulations for the construction of African identities during the twentieth century.

\section{Michael Jackson: imitation and appropriation of a global black icon in Libreville}

On the 12 February 1992, Michael Jackson set foot on the tarmac of Libreville's airport, welcomed by thousands of citizens. During the Gabonese stop of his African Tour, he did not perform in any show, but received a medal from the hands of President Bongo, and visited the country in his company, assisting with many performances of local 'traditional' dance companies. 
The discovery of Michael Jackson during the 1980s, and his coming to Libreville in 1992, initiated for the Gabonese youth several processes of cultural appropriation and a shifting in body practices, aesthetics and dress codes, while hip-hop culture was spreading within the urban youth of Gabon. Even if Michael Jackson is not usually included in the domain of hip-hop culture, and is rather considered as a pop artist, he was received in Gabon at a period where people did not clearly identify genre distinctions among the new aesthetics and urban movements observed in movies or rap video-clips. They did not distinguish between the different genres received. Until 1990, the teenagers of Libreville borrowed dance moves indistinctly from the different new youth cultures of the United States, often with no clear distinction and categorizations between Michael Jackson, pop and hip-hop, ${ }^{11}$ all participating in an urban, young and black American culture.

Among the people I met during my ethnographic research - rappers, managers, hiphop dancers or others members of hip-hop movement - many started their careers imitating Michael Jackson, before truly entering the hip-hop world (and distinguishing hip-hop from Jackson's pop music or dance style). One rapper recounts with the following words about how the discovery of Michael Jackson and the appreciation of his music is interpreted in the framework of racial issues:

Michael is someone who has inspired success in black Americans, during a period where it was rare to see Black people in show business. There was Diana Ross, Stevie Wonder, etc. But the impact of Michael Jackson ... The difference is that Michael Jackson has been the biggest star of the century. [...] Here, with Michael Jackson, we didn't think anymore of the black man as a thief, as a bandit, but that guy came to give another image of the Black man. Like that, as we say in Wesley Snipes' movies that 'White men can't jump', we have said 'White men can't do what Michael Jackson does'. And this has made us proud to be black, because this was not about bad news items [faits divers] or robberies: it was a positive image. (Interview with Lou-Ori J, rapper and history teacher, August 2011, Libreville)

For Lou-Ori J (here quoted), his music, above all, has carried a new representation of black men. When we look at the memories of this generation of the 1980s, Michael Jackson was the new emblem of a black artist, whose talent was celebrated internationally. Beyond the issue of black pride, Michael Jackson also represented for this generation the way of life of 'modern' Western cities, as his music videos demonstrated, and an urban black life anchored in another model of 'modernity', this ideological paradigm that has been imposed as the national and individual objective since colonization.

Since the 1980s, contests of Michael Jackson's dance style have multiplied and imitators of Michael Jackson have flourished, with the aim to appropriate the charisma of this black icon. For example, the singer and dancer Landry Ifouta, raised in the coastal town of Port-Gentil in a middle-class family, started to imitate the 'King of Pop' in 1982, before he became a famous singer of zouk and other popular music in Gabon. He describes his discovery of Michael Jackson as a 'trigger' or a window opening on to the world, and to the African-American world particularly:

Us, we didn't even know that blacks had left from here to be slaves and had become black Americans. We didn't know anything. Michael Jackson has been for me the trigger with which to encounter the modern world, well, the western world, the United States of America.

French music, my parents were already forced to listen to French music. We just got out from the FEA [French Equatorial Africa]. So, it's a history that we are confronted to since the first 
school classes. [...] So there will be those cultures that will mix inside of us. But the culture that will really contact us with the world, it's Michael Jackson. Here is what he has revealed to me: he has revealed to me that there is not only Gabon. After France, there is the United States of America. There is a history with black men, there are some black men there that arrived from Africa. (Interview with Landry Ifouta, singer and dancer, June 2011, Libreville)

Here, the reception of Michael Jackson's music, dance and personality leads to the encounter with ideological claims about the black condition, and with the history of a black diaspora that was sometimes unknown in Gabon, because of school and media that were still clearly orientated towards the postcolonial relationship with France. Contrary to the model imposed during colonization and followed during the first times of independence by the previous generation, Michael Jackson, hip-hop icons and more broadly African-American musicians whose music was spread around the Africa continent carried for this generation an alternative form of entry into a 'counter-culture of modernity' (Gilroy 1993).

To understand the political and cultural stakes underlying the process of cultural appropriation of this figure, it is meaningful to pay attention to the steps of reception and adoption of his dance and music style, and to the forms of differentiation that emerged, regarding the local context and history. A first gap between Michael Jackson's reception in the USA and in Gabon happened with regard to the different moments of Michael Jackson's career and the polemics that rose over his evolution as a performer with a strong public image. At the beginning of the 1990s, he was the victim of controversies in the United States and the lightening of his complexion (due to vitiligo) that started during the 1980s was the subject of polemics within the African-American community. ${ }^{12}$ Then, the accusations of child sexual molestation further tarnished his reputation and fed the media's attacks. ${ }^{13}$ As a consequence, and since the end of the 1980s, media critics started to offer a negative representation of Michael Jackson, criticized for his difference and eccentricities (Fast 2010; Woodward 2014), ${ }^{14}$ and this until his death in 2009.

However, in Gabon, the popularity of the artist and of his imitators did not encounter the same troubles, where during the 1990s, he was unanimously adulated by fans and by the media. The crowd, the authorities as well as the newspapers acclaimed his coming in Gabon in 1992, and declared to him 'Welcome home', celebrating his trip as a move back to his African roots (L'Union, February 1992). When he travelled to the interior towns of Gabon, and attended the performances of ceremonial and ritual initiation dances presented especially for his arrival, the national media interpreted his head movements to the rhythm of traditional dances as follows:

His African blood has answered the call of our millenary tam-tam. [...] Michael Jackson, the child of the local land, has been baptised. Despite his present colour skin, he will always stay in your heart as a brother, an African. (L'Union, Friday 14 February 1992, M.C. Ininghouet, 3)

After his visit to Gabon, Michael Jackson was even given a Gabonese nick name that is often used by Gabonese to talk about him in the current day: Mikala, an adaptation of Michael in the local punu language of the South Gabon.

Furthermore, the increasing success of some of Michael Jackson's imitators in the 1990s witnessed the development of careers that distanced themselves from their model. The process of the appropriation of Michael Jackson's music and dance style had been engaged progressively, involving a cultural transfer that drew away from the 
American reception of Michael Jackson, for these artists to create their own readings of this globalized phenomenon, and their own creations. The pathway and creations of the dancer Michael Anicet shows clearly the main cultural strands of Michael Jackson's appropriation in Gabon, as I now will describe in detail.

\section{From Michael Jackson to Michael Anicet: the path of appropriation}

An unfailing supporter of the singer to whom he often pays tribute, Michael Anicet is known and liked in Gabon for his talents as a dancer and imitator of Michael Jackson's moves, but maybe even more because he has created his own style: he has 'gabonized' the dance invented by this international star. Born in Libreville on 22 January 1976, he grew up in a family of seven children and a mother who was a state employee at the ministry of mining. During his childhood in the worker's housing estate of Likouala, like many young people of his age, the urban dances he discovered on TV and popular shows rapidly became one of his favourite leisure time pursuits. With the release of the song Beat It, he was fascinated by this black singer, the generator of a revolutionary style that enthralled the youth of the African cities. On 11 February 1992, he played truant from school to go to the airport with his comrades to attend the arrival of Michael Jackson. He mingled with a jubilant crowd spread over the whole seaside road, and he even succeeded in brushing against the star's hand. Anicet describes this encounter as the stimulus that gave birth to the 'little Michael' that was growing inside of him. After this event, he decided to create his own dance group with one of his sisters and a neighbour. He started to frequent dance contests and to challenge the other imitators of the star, winning all the competitions. Then, in the aim to 'professionalize' his practice, he gathered several dancers or amateurs, and he progressively developed a series of choreographies inspired by Jackson's most famous videos. Thanks to the support of his networks, he found markets and spectacles, and he rapidly rose to fame as a dancer and a company director in the capital, animating weddings, birthdays and shows in Libreville and other Gabonese cities.

Currently, Anicet's troupe performs to packed houses and gathers a heterogeneous audience, with as many expatriates of the Western world as Gabonese people. His troupe includes a large number of dancers, coming mainly from hip-hop companies. Formerly, hip-hop dance and Michael Jackson's dance style competitions used to be performed mainly in the streets or the courtyard, through improvization battles. Dancers were competing against each other, often in circles, and they ad-libbed their movements freely. Contrarily, Anicet's shows constitute a clever mix of several choreographies rigorously orchestrated and synchronized, due to long hours of rehearsal and to a strict discipline. Often presented as tributes to the dead icon, the shows contain an important number of choreographies, where Anicet represents the many facets that Michael Jackson has taken on during his life, from the white and golden suit and tie of 'Smooth Criminal' ${ }^{15}$ to the leather outfit of 'Thriller'16 (Figure 1).

In the choreography of 'Remember the time', ${ }^{17}$ he replays with his dancers the representation of the pharaoh's court staged in the music video released by Michael Jackson and Spike Lee in 1992, ${ }^{18}$ appearing in a white and gold glossy suit, within a set made of palm leaves and royal thrones (Figure 2).

Among his performances, the choreography that Anicet and his audience like the most is the one assembled around the tracks 'They don't care about us' and 'Black or white', ${ }^{19}$ the 


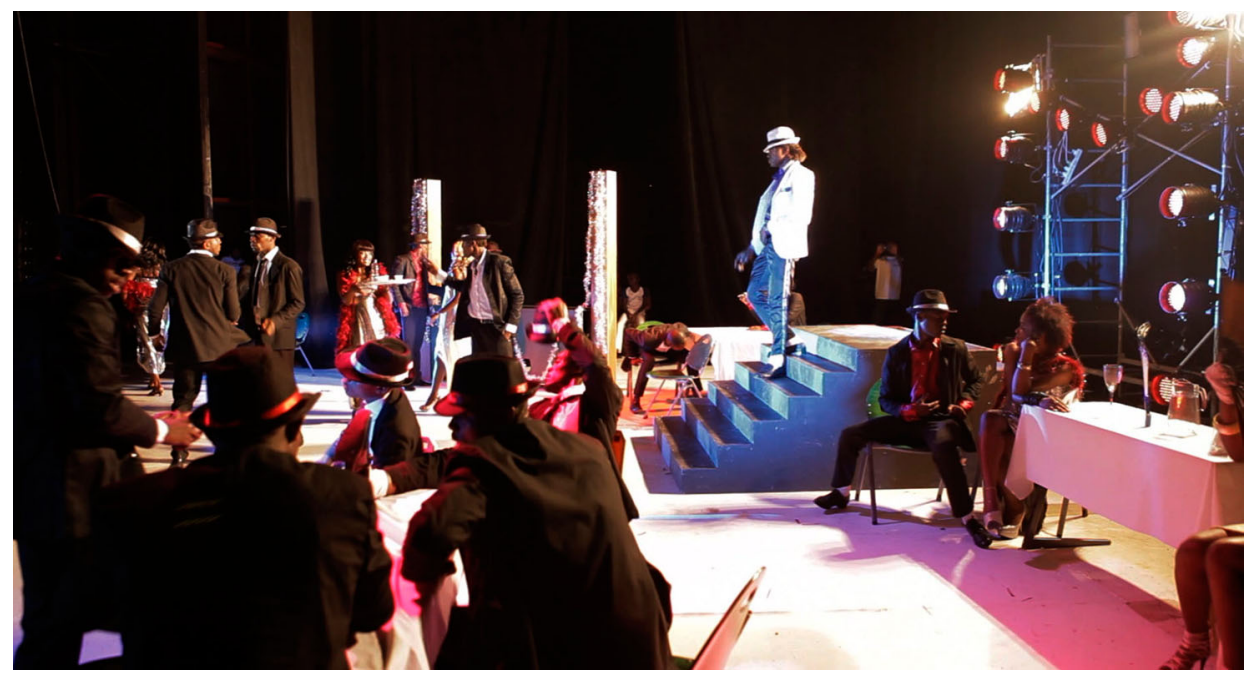

Figure 1. Michael Anicet and his troupe performing Smooth Criminal. Aterianus-Owanga, $\odot 2013^{20}$

first choreography that he took over. If these two tracks play such an important role in Anicet's message, it is precisely because they represent the most engaged titles of Michael Jackson regarding the discriminations of black people and race issues. Indeed, the lyrics of the song 'They don't care about us' denounce the marginalization and alienation of oppressed people, Black people in this instance. Even if Michael Jackson had already challenged racial categories before (Martin 2012; Chin 2011), this song presents - from some authors' point of view (Rossiter 2012) - a remarkable turn in the singer's work: with this piece, he incorporated for the first time te symbols and claims of the Black Nationalist movements, answering also to the diverse charges and critics made against him (Fast 2015, 79).

Moreover, when Michael Jackson's route became more and more transnational, especially through his involvement in several charity and humanitarian associations around the world, one of the two music videos of 'They don't care about us' also

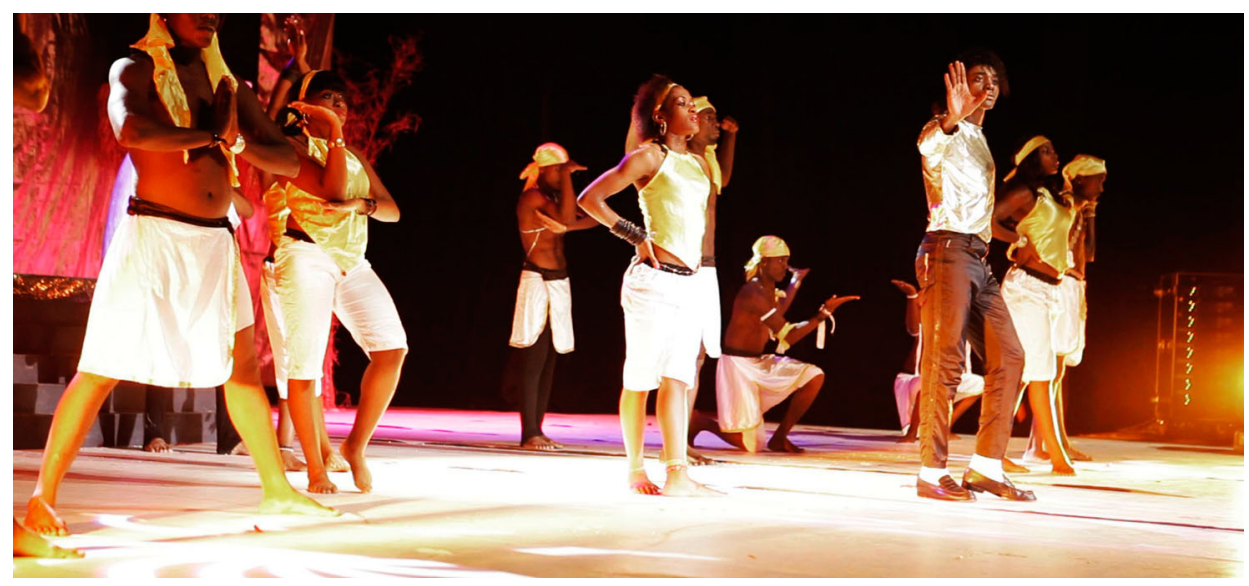

Figure 2. Michael Anicet and his dancers performing the choreography 'Remember the time'. Aterianus-Owanga, (c) 2013 
proved his commitment to a transnational black diaspora and the memory of slavery (Martin 2012; Rossiter 2012): before shooting a second version of the video in a prison, the first and most famous video of this song - directed by Spike Lee - had been shot in the Brazilian site of Pelourinho, within the city of Salvador, a historical place for the memory of the slave trade and black suffering (Martin 2012). Accompanied by the music group Olodum, the clip expressed 'an artistic act of reverence and reclamation' (Martin 2012), and it signified Jackson's commitment to a transnational memory of slavery and a black community; it asserted more than ever his African roots and his Black Atlantic belonging, and proved his connections with some main personalities for the involvement towards African-American populations' rights and history in the United States, such as Spike Lee (Grant 1998). In the United States, even before the official release of the song, many voices had risen up against the presence of lyrics considered as anti-Semitic. ${ }^{21}$ Michael Jackson had denied these allegations and had explained that he was at contrary identifying in this track to all the discriminated people, but he and his label had nevertheless taken these critics into account, and he had modified a part of the lyrics before the release of the official version (Taraborrelli 2009, 608).

Yet, the piece 'They don't care about us' exerts precisely a strong importance for Michael Anicet because it testifies to Michael Jackson's involvement against racial discriminations, exploitation, domination and relegation of Black people. In December 2012, during a spectacle organized in the French Institute of Gabon, Anicet revealed to the audience the reasons why he insists on these two tracks in his performances: because of the strong engagement in the Black and African history that they support. Often hidden across the Atlantic by the debates about his depigmentation and his androgynous appearance (Vigo 2010), the implication of Michael Jackson in black people's advancement is brought back in the audience's memory during Anicet's shows, and he reminds his spectators of the artist's work for the access to recognition of Black talents. Thus, contrary to the United States, where the star's path and complexion are still the subject of debates in the black American population, Michael Jackson is becoming in Gabon, through the voice of Michael Anicet, the medium for memories and ideologies that valorize blackness and black pride. Whereas in the United States, the star defended a universalist and antiracist discourse about this track (Rossiter 2012), in line with the American ideology of postracial harmony (Peretz 2013), in Gabon, for Anicet and for the dancers who have been inspired by Michael Jackson, this song is above all a cry of resistance against the oppression of Black men.

As Marc Perry argues about hip-hop, dance and body practice enable a 'global (re)mapping of black political imaginaries' (Perry 2011, 310) in Gabon. Therefore, this appropriation and connection to a 'transnational blackness' (Marable and Agard-Jones 2008) through dance is also the lever to an important assertion of nationhood, turning the racial claim for blackness into a nationalist claim, as we will see below with a more precise description of the performance of the medley 'They don't care about us' and 'Black or white'.

\section{From blackness to gabon-ness: Michael Anicet's gabonization of Michael Jackson}

This medley is interesting for understanding the appropriation of Michael Jackson's dance style also because it allows us to see how Michael Anicet has tried to 'gabonize' his dance 
style and to localize it, achieving through this his cultural appropriation. It is indeed in this medley that Anicet incorporates many typical and 'traditional' elements of Gabon. At the end of the title 'They don't care about us', he performs at the centre of the stage with two female dancers who are clothed with raffia, straw garments that are used in traditional ceremonies of many ethnic groups in Gabon. In the choreography, the two young female dancers wearing this emblem of local 'tradition' follow on the bust and hips dance movements of the lingwala dance from the South-East of Gabon. ${ }^{22}$ In the rest of the choreography, during the transition of the two tracks, a group of dancers scatters across the stage, with the instruction to improvise movements based on a Gabonese dance, whether it be ikoku, nyembè, bwiti, ou mbatswa. ${ }^{23}$ This short moment in the choreography (where Anicet and his dancers pull themselves out of Michael Jackson's dance style) introduces a mix of Gabonese dance stemming from different ethnic groups, in the aim to create something local. Anicet then adds to an afro-contemporary choreography with two dancers who wear loose wax trousers, ${ }^{24}$ just as the moment of the clip where Michael Jackson dances in the bush with African dancers, before reproducing the moment of the video where Michael Jackson dances with two Native Americans. He continues his copying and adaptation of the song 'Black or white' with the arrival of an Indian female dancer dressed with an imitation of a sari, where he reproduces the movements of Michael Jackson in the streets, before gathering all the dancers for a final human pyramid (Figure 3).

During the 2012 show described above, Michael Anicet explained in a speech to the audience his adaptation of these two songs: he stated another point of view about the song 'They don't care about us' and about Michael Jackson's relationship towards Africa, where he expressed this time a specifically nationalist pride. He reminded the spectators of a hitherto unknown dimension of this piece: the fact that Michael Jackson had used as a background an obamba ${ }^{25}$ rhythm from the East of Gabon (the rhythm and dance named ngwata), that, according to Anicet and several Gabonese of this generation with whom I have spoken, ${ }^{26}$ would have been discovered by the singer during his 1992

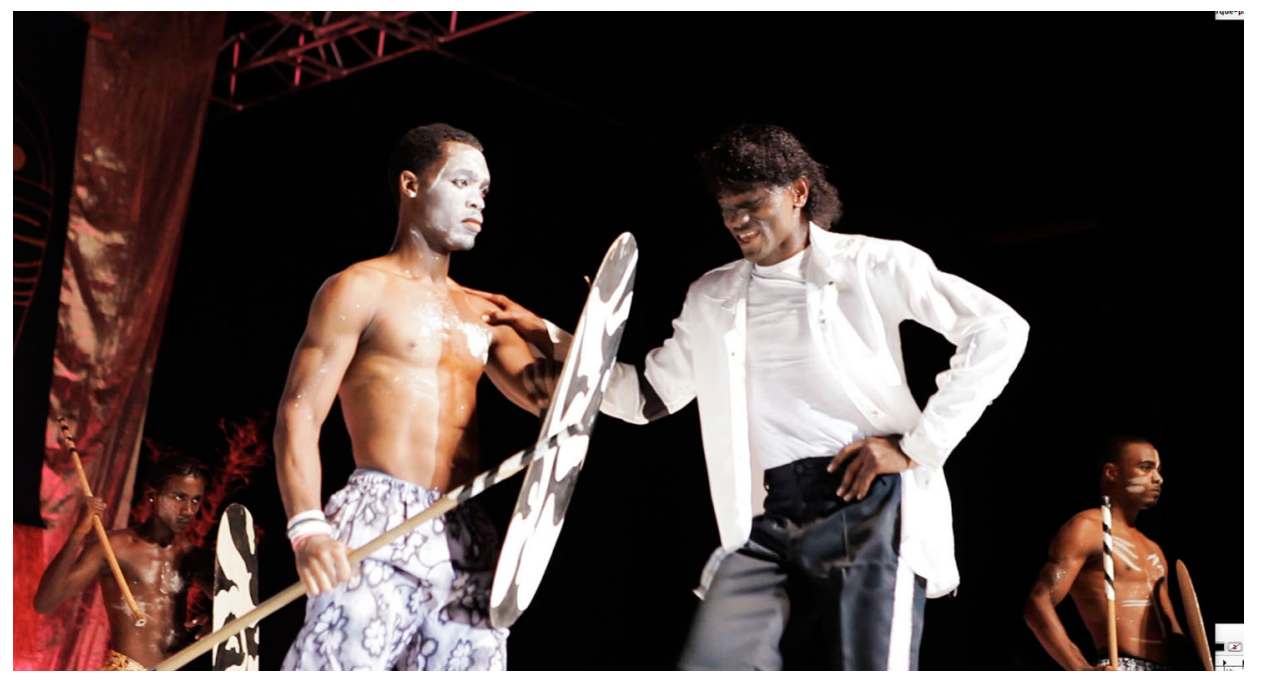

Figure 3. Michael Anicet performing the song 'Black or white', and reproducing Michael Jackson's dance video on stage. Aterianus-Owanga, ( $) 2013$ 
trip in the Gabonese hinterland. This association is however not confirmed by the academic scholarship devoted to Michael Jackson's work (Vogel 2011, 192; Knopper 2016, 232), and musical analysis ${ }^{27}$ has highlighted that there was no clear similitude in the rhythmic formula of Michael Jackson's 'They don't care about us' with ngwata or batéké songs.

Even if they do not proceed to a musicology analysis, the Gabonese roots of this song are proved from Anicet's and other Gabonese people's point of view by the 'rhythmic' similitude between the song and the ngwata genre or genres from the High-Ogooué province, ${ }^{28}$ and by the fact that the song was released a few years after Michael Jackson's arrival in Gabon. Anicet goes further on his explanations about this song in the following extract of an interview:

In this song, he makes a little return to the roots; he really marks his belonging to African-ness. For me, this is a song that carries hope, above all to us who are in the African continent. And me, I have appropriated that song. To show how much I have understood that song, and to understand the struggle he fought for, I have gabonised it. I have gabonised this song by highlighting the traditional Gabonese folklores, and by adding all dance moves of my province, the Ogooué-Lolo and of the provinces around my province. ${ }^{29}$

Because of these supposed similitudes between ngwata rhythm and 'They don't care about us', for Anicet this song has become the way to combine the identification to a transnational black diaspora with the expression of a nationalist speech in his performances. Anicet does not belong to the ethnic group of the Haut-Ogooué, but he puts forward here a nationalist belonging that includes all ethnic groups and provinces. In his performance, his attachment to the Gabonese nation is for example manifested in the addition of traditional or dances such as the dances described previously, but also at the end of his shows, when he and his dancers wave a giant Gabon-shaped wood board, and two flags: one of the green-yellow-blue national colours of Gabon, the other of the colours of the United States. While there are no strong historical political relationships between Gabon and the United States (unlike with France), this demonstration materializes the identification and cultural linkages built with the United States around the appropriation of Michael Jackson, and more broadly through the reception and consumption of Black American singers.

Thus, whereas the title 'They don't care about us' was considered in the United States as the mark of Michael Jackson's new connection with Black nationalisms, Michael Anicet takes ownership of this song to elaborate a reconnection to Africa and to the Gabonese nation in particular. In doing so, he brings together the representation of Black, African and Gabonese identity in one move, mixing the music of Michael Jackson and the claim for a Black transnational nation with his own nationalist feelings and attachments, thanks to the outfits, rhythms, steps and dance moves he invents or reinvents. And so, whereas Michael Jackson's route around the world and the black Atlantic has transformed him from a national icon into a global icon (Martin 2012), his appropriation in Gabon has been driven in the opposite direction, converting this global symbol of a transnational black pride and community into a lever for a national identity construction.

To support this idea regarding the construction of nation through a local appropriation of a transnational dance practice, we can add that for several dancers who take over Michael Jackson's choreographies and gestures, the matter is really more to capture the power of a western modernity carried by some African-Americans icons in the aim to insert it in new 
creations, than to limit themselves to a sole imitation. Other famous imitators who have preceded Anicet in Gabon have known other destinies, but the bifurcations in their routes confirm also the effects of cultural refraction and national identity construction inspired by Michael Jackson's pieces. The singer Landry Ifouta that I quoted at the beginning of this paper has for example started to imitate Michael Jackson wearing long and curled hair, and taking over his songs, dances and choreographies. However, over his solo career, the identification with Michael Jackson has lessened step by step, making way for a new musical and dancing genre: after having created songs in the local rumba, he is now famous for his songs in the genre African zouk or coupé-decalé, ${ }^{30}$ that contain Gabonese accents and lyrics in myènè language, and that deal more with thematics concerning Gabonese daily life, love stories and values. Landry Ifouta's videos and shows are now more turned into the presentation of ndombolo or coupé-decalé dances, in order to create an urban Gabonese dance style. Interviewed about his career and musical choices, Landry Ifouta explains that he has progressively followed the advices of his close friend and relatives, for who the consecration as a singer could never happen through imitation, and for whom it was necessary to sing in his own language.

Here Michael Jackson is at the same time the creative inspiration of new music and dance styles, the proof of new possibilities of recognition for Black talent, and the call for a construction of particularizing features that are typically Gabonese. This gabonization passes by subtle transformations of Michael Jackson's dance style with local moves (like Michael Anicet, who became for the audience the 'Gabonese Michael') or by the insertion of Michael Jackson's dance moves in an African zouk genre (like Landry Ifouta).

\section{Conclusion}

This essay has shown how the appropriation of Michael Jackson's dance, music and discourses have accompanied the construction of overlapping identities in a particular period of the Gabonese history and state construction. From the 1980s onwards, Gabonese urban youth have experienced shifts in their models of modernity. They have used the adoption of a global youth culture, hip-hop, as a tool to both imagine themselves in the world and to create a sense of the local. Following on the adoption of several other African-American music genres, and simultaneously to the appropriation of hiphop, the practice of Michael Jackson's dance has allowed the creation of new local circles of socialization and recognition for the youth, and at the same time it has accompanied the involvement into a global black popular culture, shaping a Gabonese version of the 'Intercultural body' (Osumare 2002).

The singular path of Michael Anicet and the observation of other artists prove that these dance practices have challenged the hegemonies and stereotypes concerning Black men, and have aimed to reshape the images of blackness and African-ness. At the same time, it appears between the lines that the imitation is in fact the place of particularization and identity construction conflating the ethnic and national referents. In sum, with these imitators' work and dances, we do not deal with the representation of a postnational transnational subject, but with a subject who negotiates and alternates between different registers of identification.

These observations refer to diverse problematics concerning the concept of the nation, and to the criticisms of the nationalist limits of Eurocentric theories by different authors. 
In several postcolonial writings, the idea was to demonstrate the fictional dimension of the nation's narratives, its permanent uncertainty and its internal divisions (Bhabha 1990), but also to split the frames of the national thought, in order to analyse the transnational circulations within the empire or other spaces of reference, and the global mechanisms anchored within the production of contemporary nationalisms (Comaroff and Comaroff 2010). For these scholars, the radical challenging of Eurocentric national conceptions was not the indicator of a postnational theoretical frame applied to the postcolonial contexts. Beyond postcolonial studies, migration and diaspora studies have also insisted on the necessity to go beyond the deadlock of 'methodological nationalism' and to propose new concepts in order to understand the complexity of the transnational field (Basch, Glick Schiller, and Szanton Blanc 1994; Beck 2006), in the realm of arts (Kiwan and Meinhof 2011) among others. Here, Gabonese dancers' observation confirm that in these postcolonial African societies, ordinary and subaltern people keep reinventing their nation through transnational dialogues, far beyond the idea of a sole state-oriented nation.

\section{Notes}

1. PK10 is a popular district of Libreville periphery, whose name follows from the expression 'Kilometric point 10', that identifies the distance from the centre of the town. Also known by the name 'Bangos', PK10 is a cosmopolitan area gathering diverse ethnic and national origins, like many other areas of Libreville (Kwenzi-Mikala 1992).

2. His real name is Jean-Anicet Ngadi, but he chose this pseudonym when he became famous, referencing his idol Michael Jackson.

3. 'Gabonizer' is the expression employed by Michael Anicet himself in several discussions and interviews, but it is also used by other artists who attempt to create a Gabonese adaptation of global genres.

4. All the interviews quoted in this paper are translated from French by myself.

5. The concept of blackness here refers to an identity category drawing on historical and social categorizations, and to a cultural product (Clarke and Thomas 2009). Studies about the black diaspora have proven how this identification was drawing on circulations and hybridizations (Gilroy 1993), and how it was negotiated with various meanings depending on contexts. As described recently by Manning Marable and Vanessa Agard-Jones, the notion of 'transnational blackness' also refers (as it does here) to people, movements or organizations who contribute to challenge the global colour line and its oppressive structure of racial inequality (Marable and Agard-Jones 2008, 7), through a form of 'racialization by below' (Marable and AgardJones 2008).

6. Une vie en Black or White, Alice Aterianus-Owanga, Princesse M. Prod./IGIS, 2013.

7. This information comes from the ethnohistorical research realized for my PhD (AterianusOwanga 2013).

8. In 2009, France was still Gabon's main economic partner, and the country where most Gabonese students went to for their university education.

9. The ideology of modernity or modernization has been at the core of the construction of African nation-states, relating to the idea of 'development'. It has also strongly influenced the cultural policies and social dynamics of African countries after the independence, in the aim to create a modern African man (see, for example, White 2006). Critical studies have analysed this ideology of modernity as a colonial paradigm that postcolonial African elites followed, 'mimicking Western values in the name of Africa's modern progress' (Araeen 2010, 277).

10. Zaïko dance was practised across the whole of central Africa during the 1970s, promoted by the famous band Zaïko Langa (White 2008, 214). Soukouss dance comes from a musical genre of the Democratic Republic of Congo, and consists of swaying hips and turning the pelvis. 
11. This mix of different dance styles, during the 1980s, allowed for the invention of a local dance style in Libreville's streets, composed of pop dance moves, hip-hop moves and Michael Jackson's dance style: the so-called classic (not to be confused with classical dancing).

12. About Michael Jackson's skin polemics, read the press articles of Greg Tate (1987) and more recently, Susan Fast's paper (2010).

13. He was acquitted of these two accusations in 2005 and it is proved that this scandal was more related to media propaganda and financial extortion (Jones 2007; Thomson 2010; Fast 2010) than to solid proof.

14. After the release of 'Thriller', Michael Jackson's albums marked disappointing sales and received reserved criticism. For some statistics about Jackson's albums sales, see Boegborn (2012).

15. Michael Jackson, Bad, Epic Records/Sony, 1987.

16. Michael Jackson, Thriller, Epic Records, 1983.

17. Michael Jackson, Dangerous, Epic Records/Sony, 1992.

18. In the original music video of the piece, Egyptian pharaohs were represented by black actors, a sign of the influence of Egyptocentrist Afrocentrism on this creation. About this piece, see Gilroy $(1993,207)$ and Fast $(2015)$.

19. 'They don't care about us', Michael Jackson, HIStory, Epic Records/Sony, 1995; 'Black or White', Michael Jackson, Dangerous, Epic Records/Sony, 1991.

20. "All pictures are screenshots from the movie Une vie en black or white (Alice Aterianus-Owanga, 2013, Princesse M. Productions), mentioned previously".

21. The first lyrics which generated the polemics were the following: 'Jew me, sue me, everybody do me. Kick me, kike me, don't you black or white me'. They have been transformed into that version: 'Do me. Sue me. Everybody do me. Kick me, Hike me. Don't you black or white me'. About this controversy, see the paper of the New York Times published at the release of the album HIStory in 1995: http://www.nytimes.com/1995/06/15/arts/in-new-lyrics-jackson-usesslurs.html.

22. Among the dances of the 40 different ethnic groups of Gabon, lingwala is a dance performed by men and women during traditional ceremonies, often in lines.

23. About the history of displacement of ceremonial and ritual dances on modern stages, see Aterianus-Owanga, forthcoming.

24. The category 'afro-contemporary dance' in Gabon (and in Africa or in some cultural networks) refers to a kind of dance that appeared during the 1990s and that is inspired by European contemporary dance.

25. The Obamba are an ethnic group present in the East of Gabon and in the Republic of Congo.

26. See, for example, the following blog of a Gabonese journalist, which reproduces this common consideration while recounting Michael Jackson's coming in Gabon: 'Ngwata is a traditional Gabonese dance which comes from Batéké plateau [...]'. After his meeting with the pygmies (Bantu people living in Gabon), Michael Jackson has decided to create a hit with this cadence, whence the track 'They Don't Care About Us'. URL: <https://reymouk. wordpress.com/2016/06/29/gabon-quand-michael-jackson-dansait-sur-du-ngwata/commentpage-1/> Consulted 3 August 2016, my translation.

27. I thank the ethnomusicologist Magali Deruyter for her musicological analysis.

28. A rhythmic ambiguity between binary and ternary can indeed be recognized in Michael Jackson's song, a technique that appears to be also extremely frequent in batéké songs of the High-Ogooué (not exclusively in of the ngwata) (Le Bomin 2004).

29. This quotation is my translation of an extract from the documentary movie about Michael Anicet mentioned earlier.

30. Coupé-décalé (literally 'cut' and 'leave') is an Ivorian dance and music style that celebrates economic success and consumption (Kohlhagen 2005).

\section{Acknowledgements}

I thank the reviewers of this paper, the editors of this issue and my colleagues Magali De Ruyter and Cara Stacey for their remarks on a first version of this text. 


\section{Disclosure statement}

No potential conflict of interest was reported by the author.

\section{References}

Araeen, Rasheed. 2010. “Modernity, Modernism and Africa's Authentic Voice." Third Text 24 (2): 277286.

Askew, Kelly M. 2002. Performing the Nation: Swahili Music and Cultural Politics in Tanzania. Chicago, IL: University of Chicago Press.

Aterianus-Owanga, Alice. 2013. "Pratiques Musicales, Pouvoir et Categories Identitaires. Une anthrologie du rap gaboma." PhD diss., University of Lyon.

Aterianus-Owanga, Alice. Forthcoming. “Un 'Janus à deux visages'. Patrimonialisations des sociétés initiatiques et de discours de la tradition chez quelques musiciens gabonais." Autrepart 80.

Basch, Linda Green, Nina Glick Schiller, and Cristina Szanton Blanc, eds. 1994. Nations Unbound. Transnational Projects, Postcolonial Predicaments, and Deterritorialized Nation-states. New York: Gordon and Breach.

Beck, Ulrich. 2006. The Cosmopolitan Vision. Translated by Ciaran Cronin. Cambridge: Polity Press.

Bhabha, Homi K. 1990. Nation and Narration. London: Routledge.

Boegborn, Steven. 2012. "Really That Bad? A Case Study on the Fifth Best-selling Album of All Time." Masters of Media. Accessed October 17. http://mastersofmedia.hum.uva.nl/2012/10/17/really-thatbad-a-case-study-on-the-fifth-best-selling-album-of-all-time/.

Chin, Elizabeth. 2011. "Michael Jackson's Panther Dance: Double Consciousness and the Uncanny Business of Performing While Black." Journal of Popular Music Studies 23 (1): 58-74. doi:10.1111/ j.1533-1598.2010.01264.x.

Clarke, Maxine Kamari, and Deborah Thomas, eds. 2009. Globalization and Race. Transformations in the Cultural Production of Blackness. Durham, NC: Duke University Press.

Comaroff, Jean, and John Comaroff. 2010. Zombies et frontières à l'ère néolibérale. Le cas de l'Afrique du Sud postapartheid. Paris: Les prairies ordinaires.

Diawara, Manthia. 1998. In Search of Africa. Cambridge: Harvard University Press.

Dorsch, Hauke. 2010. "Indépendance Cha Cha': African Pop Music Since the Independence Era." Africa Spectrum 45 (3): 131-146.

Fast, Susan. 2010. "Difference that Exceeded Understanding: Remembering Michael Jackson (19582009)." Popular Music and Society 33 (2): 259-266.

Fast, Susan. 2015. Michael Jackson's Dangerous. London: Bloomsbury.

Gilroy, Paul. 1993. The Black Atlantic. Modernity and Double Consciousness. Cambridge: Harvard University Press.

Grant, Adrian. 1998. Michael Jackson: Making History. London: Omnibus Press.

Jones, Aphrodite. 2007. Michael Jackson Conspiracy. Bloomington, IN: IUniverse.

Kelley, Robin D. G. 2012. Africa Speaks, America Answers: Modern Jazz in Revolutionary Times. Cambridge, MA: Harvard University Press.

Kiwan, Nadia, and Ulrike H. Meinhof. 2011. Cultural Globalisation and Music: African Artists in Transnational Networks. Basingstoke: Palgrave Macmillan.

Knopper, Steve. 2016. MJ: The Genius of Michael Jackson. New York: Simon and Schuster.

Kohlhagen, Dominik. 2005. "Frime, escroquerie et cosmopolitisme. Le succès du "coupé-décalé » en Afrique et ailleurs." Politique africaine 100 (4): 92-105.

Kwenzi-Mikala, Jerôme T. 1992. "Présentation géo-linguistique de Libreville." Pholia 7: 67-75.

Lasserre, Guy. 1958. Libreville, la ville et sa région (Gabon, A.E.F.): étude de géographie humaine. Paris: Ouvrage publié avec le concours du CNRS par A. Colin.

Le Bomin, Sylvie. 2004. Musiques Bateke-Mpa Atege (Gabon). Gabon/St Maur-des-fossés: Editions Sépia.

Marable, M., and Vanessa Agard-Jones. 2008. Transnational Blackness: Navigating the Global Color Line. London: Palgrave Macmillan.

Martin, Sylvia J. 2012. “The Roots and Routes of Michael Jackson's Global Identity." Society 49 (3): 284-290. 
Matory, J. Lorand. 2006. "The New World Surrounds an Ocean: On the Live Dialogue Between African and African American Cultures." In Afro-Atlantic Dialogues, edited by Kevin Yelvington, 151-192. Santa Fe, NM: School of American Research.

M'Bokolo, Elikia. 2009. Médiations africaines. Omar Bongo et les défis diplomatiques d'un continent. Paris: Hachette.

Ndombet, Wilson-André. 2009. Partis politiques et unité nationale au Gabon. Paris: Karthala.

Neveu Kringelbach, Hélène. 2014. "Choreographic Revival, Elite Nationalism, and Postcolonial Appropriation in Senegal." In The Oxford Handbook of Music Revival, edited by Caroline Bithell and Juniper Hill [Online]. doi:10.1093/oxfordhb/9780199765034.013.0292013.

Neveu Kringelbach, Hélène, and Jonathan Skinner. 2012. Dancing Cultures: Globalization, Tourism and Identity in the Anthropology of Dance. Oxford: Berghahn Books.

Nguema Minko, Emmanuelle. 2010. Gabon: I'unité nationale ou la rancune comme mode de gouvernance. Paris: L'Harmattan.

Obiang, Jean-François. 2007. France-Gabon: pratiques clientélaires et logiques d'État dans les relations franco-africaines. Paris: Karthala.

Osumare, Halifu. 2002. "Global Breakdancing and the Intercultural Body." Dance Research Journal 34 (2): 30-45.

Peretz, Pauline (dir.). 2013. L'Amérique post-raciale ? Paris: PUF.

Perry, Marc D. 2011. "Global Black Self-fashionings: Hip Hop as Diasporic Space." In That's the Joint. The Hip-Hop Studies Reader, edited by M. Forman and M. A. Neal, 294-314. New York: Routledge.

Plageman, Nate. 2012. Highlife Saturday Night: Popular Music and Social Change in Urban Ghana. Bloomington: Indiana University Press.

Pourtier, Roland. 1989. Le Gabon. Paris: L'Harmattan.

Reed, Michael C. 1987. "Gabon: A Neo-colonial Enclave of Enduring French Interest." The Journal of Modern African Studies 25 (2): 283-320.

Rossiter, Brian. 2012. “'They Don't Care About Us': Michael Jackson's Black Nationalism." Popular Music and Society 35 (2): 203-222.

Sansone, Livio, Boubacar Barry, and Elisée Soumonni. 2010. La construction transatlantique d'identités noires: Entre Afrique et Amériques. Paris: KARTHALA Editions.

Taraborrelli, J. Randy. 2009. Michael Jackson: The Magic, the Madness, the Whole Story, 1958-2009. Paris: Hachette.

Tate, Greg. 1987. "I'm White! What's Wrong With Michael Jackson." Village Voice, September 22, 15-17.

Thomson, Charles. 2010. "One of the Most Shameful Episodes in Journalistic History." Huffington Post, June 13. http://www.huffingtonpost.com/charles-thomson/one-of-the-most-shameful_b_610258. html.

Turino, Thomas. 2000. Nationalists, Cosmopolitans, and Popular Music in Zimbabwe. Chicago, IL: University of Chicago Press.

Vigo, Julian. 2010. "Metaphor of Hybridity: The Body of Michael Jackson." The Journal of Pan African Studies 3 (7): 29-41.

Vogel, Joseph. 2011. Man in the Music: The Creative Life and Work of Michael Jackson. New York: Sterling Publishing.

White, Bob W. 2006. “L'incroyable machine d'authenticité : L'animation politique et l'usage public de la culture dans le Zaïre de Mobutu." Anthropologie et Sociétés 30 (2). http://id.erudit.org/iderudit/ $014113 a r$.

White, Bob W. 2008. Rumba Rules: The Politics of Dance Music in Mobutu's Zaire. Durham, NC: Duke University Press.

Woodward, Susan. 2014. Otherness and Power: Michael Jackson and His Media Critics. Dorset: Blackmore. 